\title{
Evaluation of Financial Performance
}

\author{
Pallavikumari, R. Ramamoorthy, K.Anitha
}

\begin{abstract}
Budgetary execution is a significant angle which impacts the long haul security, productivity and liquidity of an association. Typically, money related proportions are said to be the parameters of the budgetary presentation. The investigation is made to assess the money related position, the operational outcomes just as budgetary advancement of a business concern. This investigation clarifies manners by which proportion examination can be of help with long-rang arranging, planning and resource the executives to fortify money related execution and help keep away from monetary troubles. The investigation not just tosses on the monetary position of a firm yet in addition fills in as a venturing stone to healing measures.
\end{abstract}

Key words: Budgetary execution, business concern, parameters

\section{INTRODUCTION}

Money related Management is that administrative action which is worried about the arranging and controlling of the association's monetary assets. In spite of the fact that it was a part of financial matters till 1983 as a different or control it is of late beginning. [1],[3],[5]

Monetary Management is worried about the obligations of the money chief in a business firm. He performs such shifted assignments as planning, money related anticipating, money the board, credit organization, venture examination and assets acquirement. The ongoing pattern towards globalization of business action has made new requests and openings in administrative fund. [2 ],[ 4],[6]

Fiscal reports are arranged and displayed for the outer clients of bookkeeping data. As these announcements are utilized by speculators and money related experts to inspect the company's exhibition so as to settle on venture choices, they ought to be arranged all around cautiously and contain as much venture choices, they ought to be arranged in all respects cautiously and contain however much data as could reasonably be expected. Arrangement of the budget summary is the obligation of top administration. The fiscal summaries are commonly arranged from the bookkeeping records kept up by the firm [8],[10] ,[12]

Revised Manuscript Received on July 22, 2019.

Pallavikumari Department of MBA, Bharath institute of Higher Education \& Research,Tamilnadu,IndiaEmail:palalvikumari@gmail.com

Mr. R. Ramamoorthy, Assistant Professor, Department of MBA,Bharath institute of Higher Education \& Research,Tamilnadu,India

Anitha.K, Department of Civil,Bharath institute of Higher Education \& Research,Tamilnadu,IndiaEmail: anithakrish26@yahoo.co.in

\section{OBJECTIVES OF THE STUDY}

i. To analyse the liquidity solvency position of the firm.

ii. To understand the profitability position of the firm.

iii. To assess the factors influencing the financial performance of the organisation.

iv. To understand the over all financial position of the company.

\section{DATA ANALYSIS AND INTERPRETATION}

\section{Fig 1 CURRENT RATIO}

\begin{tabular}{|c|c|c|c|}
\hline Year & $\begin{array}{c}\text { Current } \\
\text { Ratio } \\
\text { Rs. in lakhs }\end{array}$ & $\begin{array}{c}\text { Current } \\
\text { Liabilities } \\
\text { Rs. in lakhs }\end{array}$ & Ratio \\
\hline $2001-2002$ & 9956.81 & 775.49 & 12.83 \\
$2002-2003$ & 8825.79 & 644.26 & 13.69 \\
$2003-2004$ & 9726.73 & 1154.12 & 8.43 \\
$2004-2005$ & 9884.64 & 1501.76 & 6.56 \\
& & & 3.06 \\
\hline
\end{tabular}

\section{Interpretation:}

As a customary rule, a present extent of $2: 1$ is seen as attractive. This standard is base on the basis that in an increasingly unfortunate condition paying little heed to whether the estimation of current assets ends up being a huge segment of, the firm will in all likelihood meet its responsibility. The present extent addresses the edge of security for leasers. The present extent has been lessening an apparently interminable measure of time after year which shows reducing working capital. 


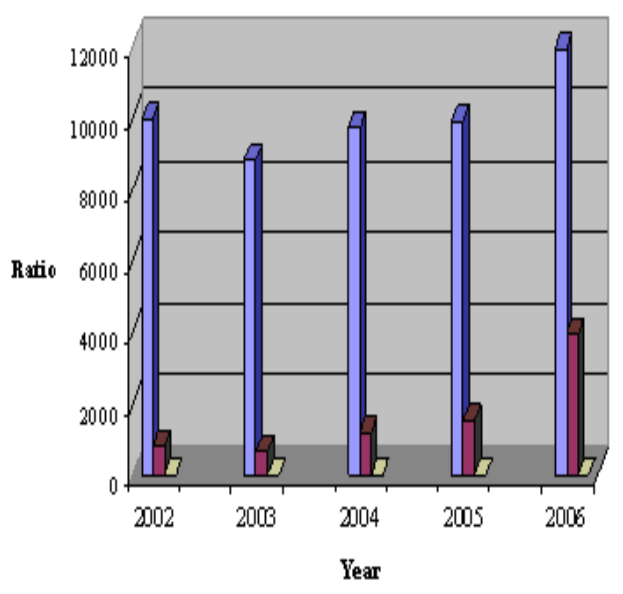

FIG 2:CURRENT RATIO

\section{INVENTORY TURNOVER RATIO}

Table 2:inventory turn over ratio

\begin{tabular}{|c|c|c|c|}
\hline Year & $\begin{array}{c}\text { Cost of goods } \\
\text { sold } \\
\text { Rs. in lakhs }\end{array}$ & $\begin{array}{c}\text { Average } \\
\text { Inventory } \\
\text { Rs. in lakhs }\end{array}$ & Ratio \\
\hline $2001-2002$ & 11209.73 & 3732.19 & 3.0 \\
$2002-2003$ & 11939.46 & 3508.00 & 3.4 \\
$2003-2004$ & 13708.36 & 3537.44 & 3.88 \\
$2004-2005$ & 12609.33 & 3385.92 & 3.72 \\
$2005-2006$ & 17543.71 & 3668.52 & 4.78 \\
\hline
\end{tabular}

\section{Interpretation:}

A higher turnover proportion is constantly advantageous to the worry. In this the occasions the stock is diverted over has been expanding starting with one year then onto the next year. This expanding turnover demonstrates quick deals. Furthermore, thusly initiates generation process and is in charge of further improvement in the business. This shows a decent stock arrangement of the organization

\section{NET PROFIT MARGIN}

Fig 3:net profit margin

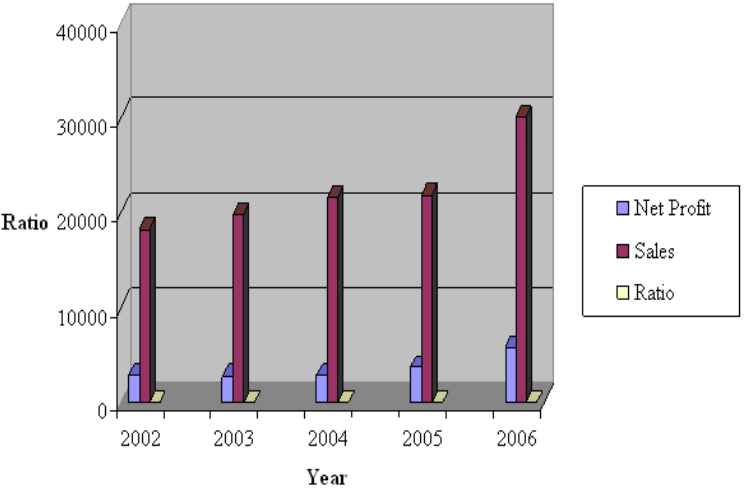

\section{RESULTS}

1) The present degree is more than 2 in all the five years. A near degree of current resources and current liabilities might be kept up since the present resources are less valuable, when veered from fixed resources.

2) The stock turnover degree fro the five years showed a decent stock procedure and ability of business activities of the affiliation.

3) The Net Profit for the five years has been developing which demonstrates that the selling and spread costs are leveled out and there is a not all that terrible operational suitability of the business concern

\section{SUGGESTION:-}

1. The Wliquidity position of the organization can be used in a superior or other successful reason.

2. The organization can be utilize the credit offices given by the lenders.

3. Efforts ought to be taken to expand the general effectiveness consequently out of capital utilized by making utilized of the accessible asset successfully.

The organization can expand its wellsprings of assets to make viable innovative work framework for more benefits in the years to come

\section{CONCLUSION}

The investigation is made on the point money related execution utilizing proportion examination with five years information. The present and fluid proportion demonstrates the transient budgetary position while obligation value and restrictive proportions demonstrates the long haul money related position. Similarly, movement proportions and benefit proportions are useful in assessing the proficiency of execution. The budgetary presentation of the organization for the five years is broke down and it is demonstrated that the organization is monetarily stable. 


\section{REFERENCES}

1) BharthVajan R., Ramachandran S.,Psychographic dimensions of training,2016,International Journal of Pharmacy and Technology,V-8,I-4,P-23727-23729

2) Balakrishnan P., Bharthvajan R.,A study on human resource planning in hospitals in Chennai City,2014,International Journal of Applied Engineering Research,V-9,I-22,P-7503-7507

3) Priyadarsini P., Bharthvajan R.,Role of emotional intelligence training programme in reducing the stress of the nurses,2014,International Journal of Applied Engineering Research,V-9,I-22,P-7411-7421

4) Kerinab Beenu G., Bharthvajan R.,Empirical analysis on the cosmetic buying behavior of young women in South India,2014,International Journal of Applied Engineering Research,V-9,I-22,P-7361-7366

5) Balakrishnan P., Bharthvajan R.,Whistling in the wind,2014,International Journal of Applied Engineering Research,V-9,I-22,P-7586-7593

6) Krishnan B., Peter M.,Health hazards of Indian Bpo employee-an alarming issue,2014,International Journal of Applied Engineering Research,V-9,I-22,P-7336-7341

7) Kerinab Beenu G.H., Peter M.,Role of insurance in economic development,2014,International Journal of Applied Engineering Research,V-9,I-22,P-7532-7539

8) Balakrishnan P., Peter M., Priyadarsini P.,Efficiency of safety measures for wellbeing of employees in manufacturing industry,2014,International Journal of Applied Engineering Research,V-9,I-22,P-7376-7382

9) Anbarasi M., Praveen Kumar S.,Online sales promotions of herbal products and its effectiveness towards tanisha.com,2019,Indian Journal of Public Health Research and Development,V-10,I-1,P-195-200

10) Anbarasi M., Praveen Kumar S.,Various online marketing and promotions strategies to improve the validation towards the organic products in the pharmaceutical sectors,2019,Indian Journal of Public Health Research and Development,V-10,I-1,P-263-269

11) Loganathan R., Praveen Kumar S.,Grievance handling a key factor for solving issues of employees in an organization,2014,International Journal of Applied Engineering Research,V-9,I-22,P-7483-7491

12) Loganathan R., Praveen Kumar S.,Study on preference of private label brands in super and Hypermarkets,2014,International Journal of Applied Engineering Research,V-9,I-22,P-7327-7335

13) Smitha M., Praveen Kumar S.,Understanding stress and its managementamong the nurses in Chennai city,2014,International Journal of Applied Engineering Research,V-9,I-22,P-7560-7565

14) Kerinab Beenu G.H., Praveen Kumar S.,A study on the investment behavior of Chennai investors in mutual fund schemes,2014,International Journal of Applied Engineering Research,V-9,I-22,P-7520-7525

15) Loganathan R., Praveen Kumar S.,Retention strategies key for organizational productivity,2014,International Journal of Applied Engineering Research,V-9,I-22,P-7443-7447

16) Pavithra J., Ganesan M., Brindha G.,State wise analysis of microfinance sector in India,2016,International Journal of Pharmacy and Technology,V-8,I-4,P-23417-23432

17) Pavithra J., Ganesan M.,A comparative study on microfinance in India and abroad,2016,International Journal of Applied Business and Economic Research,V-14,I-8,P-5471-5476

18) Pavithra J., Ganesan M.,A study on awareness and impact of micro-financial schemes,2016,International Journal of Applied Business and Economic Research,V-14,I-8,P-5449-5460

19) Senthilmurugan P., Pavithra J.,Consumer preference towards organised retailing with reference to Big Bazaar,2014,International Journal of Applied Engineering Research,V-9,I-22,P-7469-7475

20) Senthilmurugan P., Pavithra J.,Implication of social media marketing in growing healthcare industry,2014,International Journal of Applied Engineering Research,V-9,I-22,P-7448-7456

21) Loganathan R., Pavithra J.,Consumer perception towards private label brand over other brands in super markets and hypermarkets,2014,International Journal of Applied Engineering Research,V-9,I-22,P-7355-7360

22) Kerinab Beenu G., Pavithra J.,Tradeâ€"off between liquidity and profitability in logistics industry,2014,International Journal of Applied Engineering Research,V-9,I-22,P-7398-7401

23) Kerinab Beenu G., Pavithra J.,A study on the prospective consumerâ $€^{\mathbf{T M}_{\mathrm{S}}}$ perception towards utility cars in Chennai city,2014,International Journal of Applied Engineering Research,V-9,I-22,P-7526-7531

24) Pavithra J., Dilli Babu P., Ambuli T.V.,A study on budgetary control at Maruti Service Masters, Chennai,2014,International Journal of Applied Business and Economic Research,V-12,I-2,P-151-161

25) Pavithra J., Dilli Babu P., Ambuli T.V.,A study on customer satisfaction of retro Garments Pvt Ltd, Chennai,2014,International Journal of Applied Business and Economic Research,V-12,I-2,P-381-391

26) Kerinab Beenu G.H., Pavithra J., Senthilmurugan P.,A study on the influence of promotional activities for TATA ARIA among consumers in Chennai,2014,International Journal of Applied Engineering Research,V-9,I-22,P-7572-7578 Bigher Education \& Research,Tamilnadu,India
Anitha.K, Assistant ProfessorDepartment of Civil,Bharath institute of Higher Education \& Research,Tamilnadu,India
27) Vijayaragavan S.P.,An investigative expert that's general FBG Technology,V-8,I-8,PP-1500-1505,Y-2017

28) Vijayaragavan S.P.,Equalization routing protocol for $\mathrm{Wi}-\mathrm{Fi}$ senso Technology,V-8,I-8,PP-1662-1666,Y-2017

29) Karthik B., Kiran Kumar T.V.U., Vijayaragavan P., Bharath Kumaran urnal of Scientific Research,V-18,I-12,PP-1803-1806,Y-2013 operating system,Middle - East Journal of Scientific Research,V

31) Jasmin M., Vigneshwaran T., Beulah Hemalatha S.,Design of power aware of Aplied Engineering Research,V-10,I-2,PP-4487-4496,Y-2015

East Journal of Scientific Research,V-20,I-9,PP-1082-1087,Y-2014

33) Jasmin M., Vigneswaran T.,Fuzzy controller for error control of on - Chip Models and Applications in Emerging Technologies, Methodology, 2017,V-2017-January,I-,PP-1-5,Y-2017

\section{AUTHORS PROFILE}

Pallavikumari Department of MBA, Bharath institute of Higher Education \& Research,Tamilnadu,India

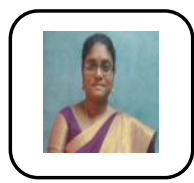

